\title{
Mitochondrial portraits of the Madeira and Açores archipelagos witness different genetic pools of its settlers
}

Received: 2 June 2003 / Accepted: 8 August 2003 / Published online: 25 September 2003

(C) Springer-Verlag 2003

\begin{abstract}
We have studied the matrilineal genetic composition of the Madeira and Açores north Atlantic archipelagos, which were settled by the Portuguese in the 15th century. Both archipelagos, and particularly Madeira, were involved in a complex commercial network established by the Portuguese, which included the trading of slaves across the Atlantic. One hundred and fifty-five mtDNAs sampled from the Madeira and 179 from the Açores archipelagos were analysed for the hypervariable segment I (HVS-I), and for haplogroup-diagnostic coding-region RFLPs. The different settlement histories of both groups of islands are well reflected in their present day mtDNA pool. Although both archipelagos show identical diversity values, they are clearly different in their haplogroup content. Madeira displays a stronger sub-Saharan imprint, with haplogroups L1-L3 constituting about $13 \%$ of the lineages. Also, the relative frequencies of $\mathrm{L}$ sub-clusters in Madeira and mainland Portugal suggests that, at least in part, African presence in Madeira can be attributed to a direct gene flow from West Africa and not via Portugal. A comparison of the genetic composition of these two archipelagos with the Canary Islands, specially taking into account that their European source population was essentially from the Iberian Peninsula, testifies the stronger impact of the North African U6 cluster in the Canaries. This group is present in Madeira at a moderate frequency, but very reduced in the Açores.
\end{abstract}

\author{
A. Brehm (更) \\ Human Genetics Laboratory, Centre of Macaronesian Studies, \\ University of Madeira, \\ Campus of Penteada, 9000 Funchal, Portugal \\ Fax: +351-291-705399, \\ e-mail: brehm@uma.pt \\ L. Pereira \\ Instituto de Patologia e Imunologia Molecular \\ da Universidade do Porto (IPATIMUP), \\ R. Dr. Roberto Frias s/n, 4200-465 Porto, Portugal \\ L. Pereira $\cdot$ A. Amorim \\ Faculdade de Ciências da Universidade do Porto, \\ Praça Gomes Teixeira, 4099-002 Porto, Portugal \\ T. Kivisild \\ Estonian Biocenter, Tartu University, Riia 24, Tartu, Estonia
}

Nevertheless the recorded introduction of Canary native Guanches, who are characterized by the presence of particular sub-clade U6b1, has left no detectable imprints in the present day population of Madeira.

\section{Introduction}

The previously uninhabited North Atlantic archipelagos of Madeira and Açores have different settlement histories since their discovery in the 15th century by the Portuguese. The colonization process of Madeira and Porto Santo started in 1420 with an assortment of Portuguese nobles, Jews, exiles, and convicts. White slaves from the Portuguese colonies in North Africa (especially Arguim in Mauritania) were introduced, together with Guanches, natives from the Canary Islands. After the discovery of the Cabo Verde islands (1462) and the beginning of the slave trade, most slaves brought to Madeira were sub-Saharans from Senegambia (the West African coast including today's Senegal and Guiné) (Carreira 1983; Russell-Wood 1998). Later, slaves were also imported from Angola and even India. In 1552 they already constituted $10 \%$ of the Madeira population and gradually became landowners, completely integrated into the society (Pereira 1989). Notably, the sub-Saharan and Moorish slaves gained their free status in Madeira as much as 300 years before the official abolition of the slave trade (Pereira 1989). After 1768 the import of African and Asiatic slaves was officially forbidden. On Madeira, toponyms related to Moors and sub-Saharans are commonplace. In addition, numerous settlers from the rest of Europe arrived in Madeira, among them Spaniards (from Galicia and Andalusia), Italians, French (Flemish and Bretons) and English. At its commercial height, the island (together with Cabo Verde) was an obligatory stop for ships involved in trade (slave or not) from the coast of Angola, the east African coast, India and later to Brazil and the Antilles (Russell-Wood 1998). In contrast, the sub-Saharan slave component in Porto Santo has been historically minor. Its settlers were mainly from the south of Portugal (Algarve), but there are records of 
multiple invasions of the island by North African pirates (Pereira 1989).

Discovered in 1432, the settlement of the Açores archipelago has been well documented. The end of the 15 th century witnessed a massive immigration of settlers from mainland Portugal, and especially from Madeira. It is known that other Europeans were among the first groups, particularly the Flemish. Tradition says that people coming from the centre and south of Portugal settled the eastern group of islands, whereas the central islands had a larger input from families coming from the north of Portugal (Mendonça 1996). Although in the island of São Miguel, the existence of a large community of Moors is already documented by a 16th century traveller (Frutuoso 1977), the number of sub-Saharan slaves in the Açores never reached the proportions that took place in Madeira.

The main aim of the present work is to analyse within the historical context mtDNA variation in Madeira and Açores and to estimate the impact of the likely source populations, including Portugal, North Africa and Cabo Verde, in the formation of the present day maternal gene pool of the islands. We also compare the mtDNA pattern of these two archipelagos with that of the Canary Islands, another archipelago mainly settled by Spaniards.

\section{Material and methods}

\section{Sampling}

A total of 334 blood samples were collected from unrelated males from the Madeira $(n=155)$ and Açores $(n=179)$ archipelagos whose maternal ancestors were known to be originally from the same island of the archipelago, at least for three generations. The samples were collected in military camps with the permission of the Chairman of the Army Chief of Staff. All donors were voluntary, gave informed consent and were submitted to an interview where the research project was explained. The Açores archipelago is usually divided into three geographic groups of islands (Western, Central and Eastern group). However, in the present paper all samples are merged into a single group, but data is available for each island in separate upon request from the authors. Similarly the data for Madeira and Porto Santo islands is pooled together (both belong to the Madeira Archipelago).

\section{HVS-I sequencing}

The leukocyte fraction of whole blood was used to extract DNA using standard methodologies. The mtDNA hypervariable segment I (HVS-I) of the control region was amplified using the primers L15996 and H16401 of Vigilant et al. (1989) with the conditions specified therein. PCR products were sequenced with the same primers used for amplification in an ABI-377 DNA Automated Sequencer (Applied Biosystems). The sequences obtained were aligned to the Cambridge reference sequence (CRS, Anderson et al. 1981) and differences were reported for nucleotide positions (nps) $16025-16389$.

\section{RFLP testing}

All digestions were carried out according to the manufacturer's instructions (Promega). Digested fragments were resolved in gels with specific acrylamide concentrations, depending on the fragment sizes, and visualized after silver staining. The following polymor- phic restriction sites were screened: 4577 NlaIII, 7025 AluI, 8994 HaeIII, 9052 HaeII, 10032 AluI, 10397 AluI, 10871 MnlI, 12308 HinfI (generated with a modified primer: Torroni et al. 1996), 12629 AvaII, 13704 Bst OI, 14766 MseI. The polymorphic positions were determined by digesting fragments amplified with primers previously published (Torroni et al. 1996), apart from $10871 \mathrm{MnlI}$, 12629 AvaII and 14766 MseI, which were checked by amplifying fragment with primers (forward and reverse) 5'-GCCATACTAGTCTTTGCCGC-3' and 5'-ATTAGGAGGGGGGTTGTTAG-3', 5'-GCCACAACCCAAACAACC-3' and 5'-CGGGCGTATCATCAACTG-3', 5'-CAATGATATGAAAAACCATC-3' and $5^{\prime}$-CCCCCTAATAAAATTAATTA-3', respectively (Toomas Kivisild, personal communication).

\section{Phylogeographic analysis}

HVS-I haplotypes were assigned to established mtDNA haplogroups when possessing an unambiguous haplogroup motif (Salas et al. 2002; Richards et al. 2000). All ambiguous cases were tested for haplogroup-diagnostic RFLPs. The classification of mtDNAs from the sub-Sahara African clades (L1a-d, L2a-d, L3b, d, e, L3*) follows Salas et al. (2002). The sub-division of West Eurasia macrohaplogroup $\mathrm{N}$ mtDNAs largely followed Richards et al. (2000). Haplogroup U5 sub-clades were re-defined on the basis of the information of complete sequences (e.g. Finnilä et al. 2000): U5a is defined by a non-synonymous transitions at $\mathrm{np} 14793$ and associates with the HVS-I motif $16256-16270$; U5b by is defined by synonymous substitutions at nps 7768 and 14182, often associated with the ambiguous motif 16189-16270 in HVS-I. Haplogroup pre-V was defined as in Torroni et al. (2001).

\section{Comparative data}

We searched for haplotype matches within our extensive database of European and African HVS-I sequences. To represent more precisely the likely source populations, we used data from Portugal (González et al. 2003; Pereira et al. 2000) subdivided into the north, central and south, from Cabo Verde (Brehm et al. 2002) and from North Africa (samples of Morocco, Mauritania and West Sahara from Rando et al. 1998). Haplogroup frequencies were used to perform a principal component analysis of the populations under study.

\section{Results and discussion}

Like in continental Portugal, the most frequent mtDNA haplogroup in both archipelagos is $\mathrm{H}$, followed by $\mathrm{U}, \mathrm{T}$, and pre- $\mathrm{V} / \mathrm{V}$ clades (Table 1 ). Two haplogroups, $\mathrm{H}$ and U5 alone account for more than one half (169 mtDNAs) of the individuals. More than $20 \%$ of the haplotypes found in Madeira (14.8\% of the samples) belong to sub-Saharan L and M1 haplogroups, against $8.7 \%$ (4.5\% of samples) found in the Açores. Although the haplogroup profiles of the islands were very similar to mainland Portugal only 13 (of the 43) haplotypes observed in Madeira or Açores had a match in Portugal (Côrte-Real et al. 1996; González et al. 2003; Pereira et al. 2000). This low proportion of haplotype sharing can be due to insufficient sampling in Portuguese source region and, on the other hand, reflect the wider source in Europe of the founding lineages. Indeed, when taking the European sample as a whole (Richards et al. 2000) then the proportion of shared haplotypes of $\mathrm{H}$ reached $\sim 80 \%$ (34/43), the unique types being one-step derivatives of common types throughout Europe. 


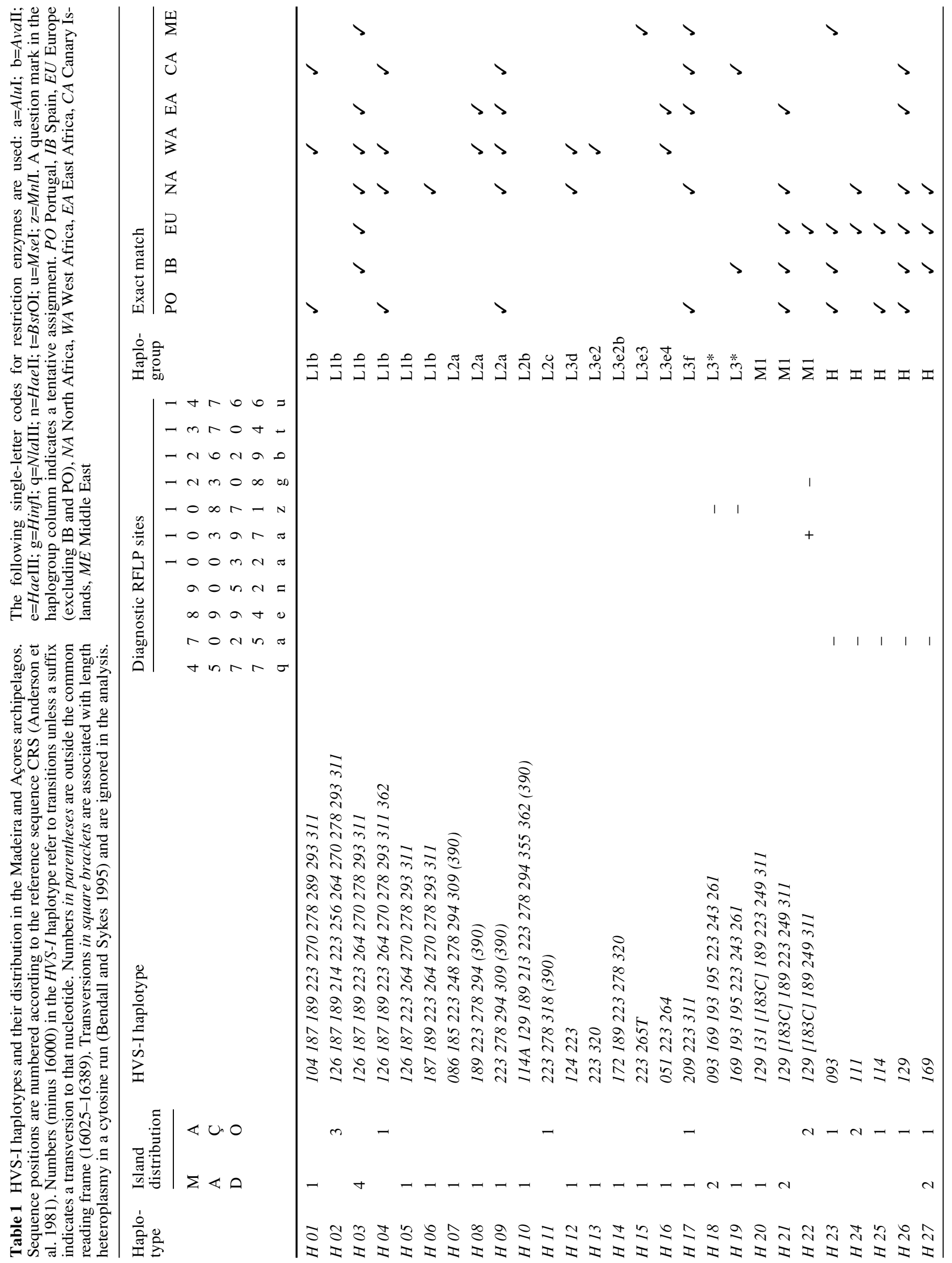




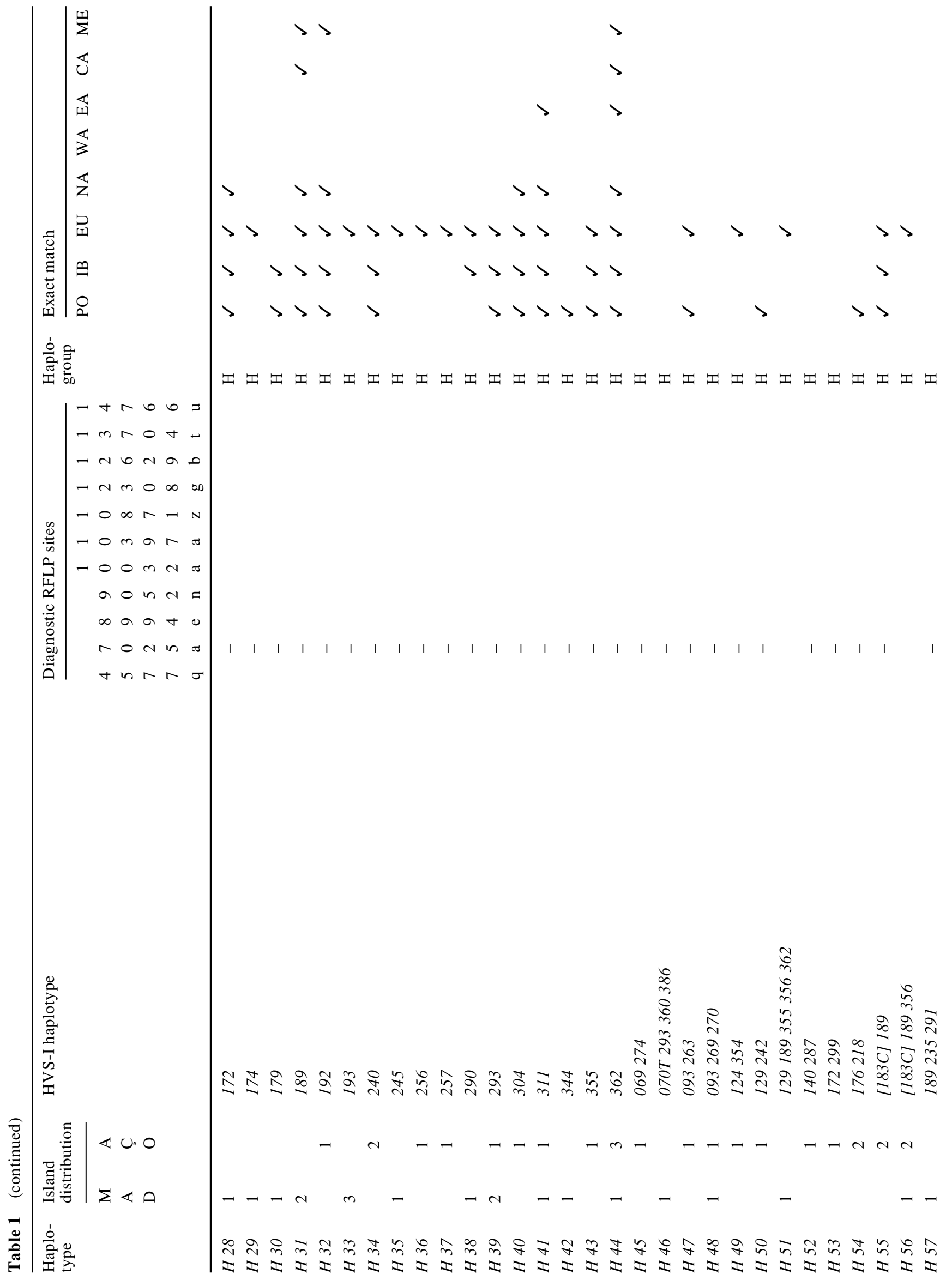




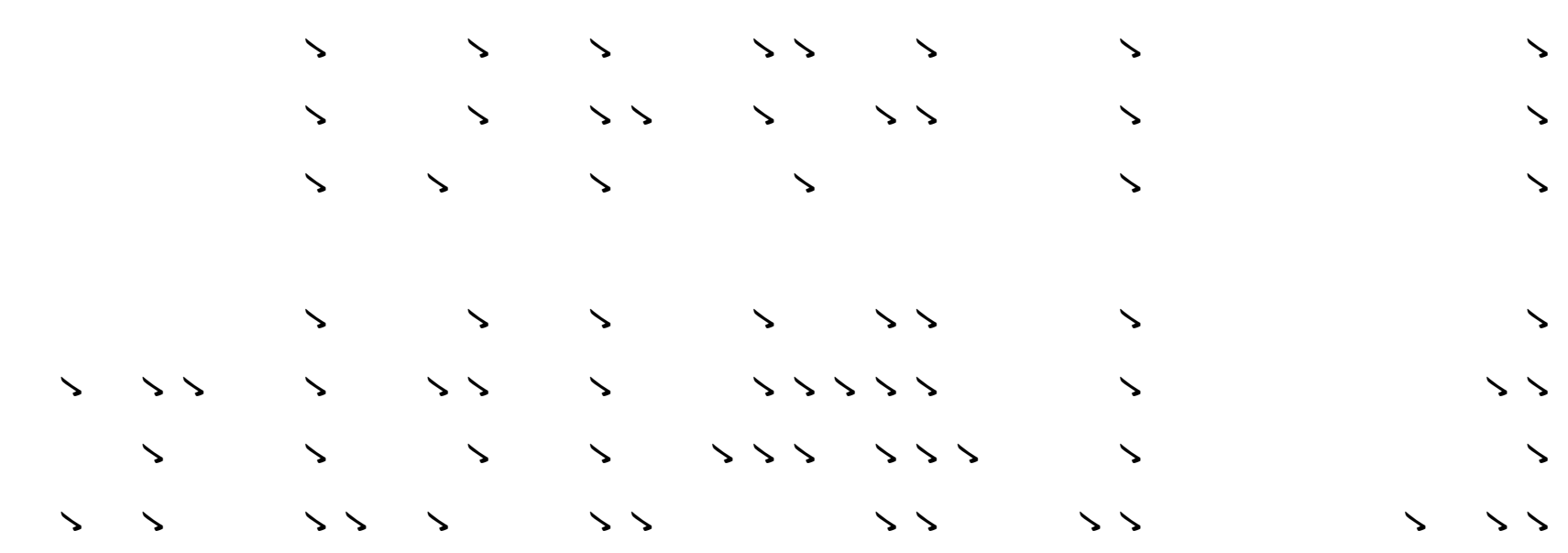

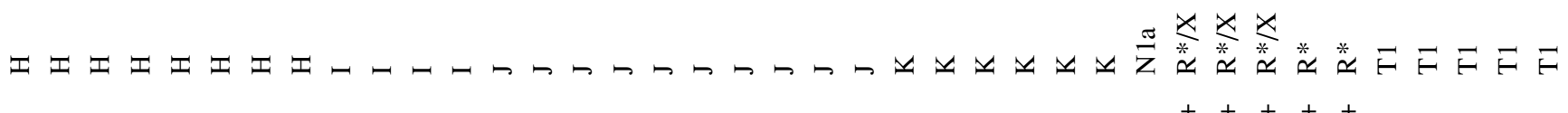

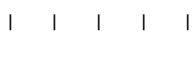

$++++$

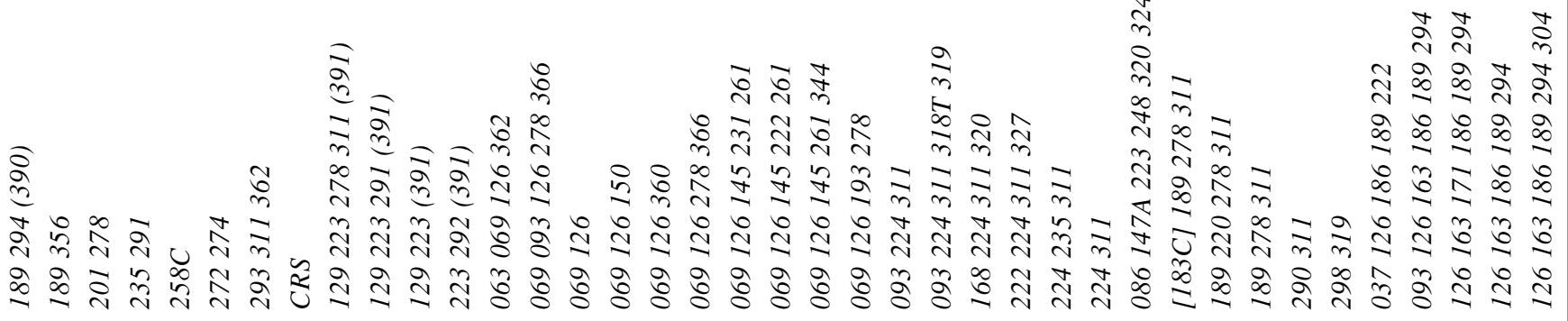

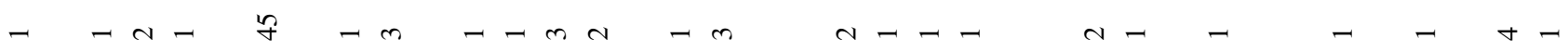

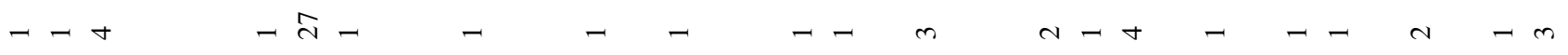

in

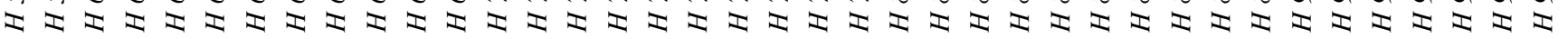




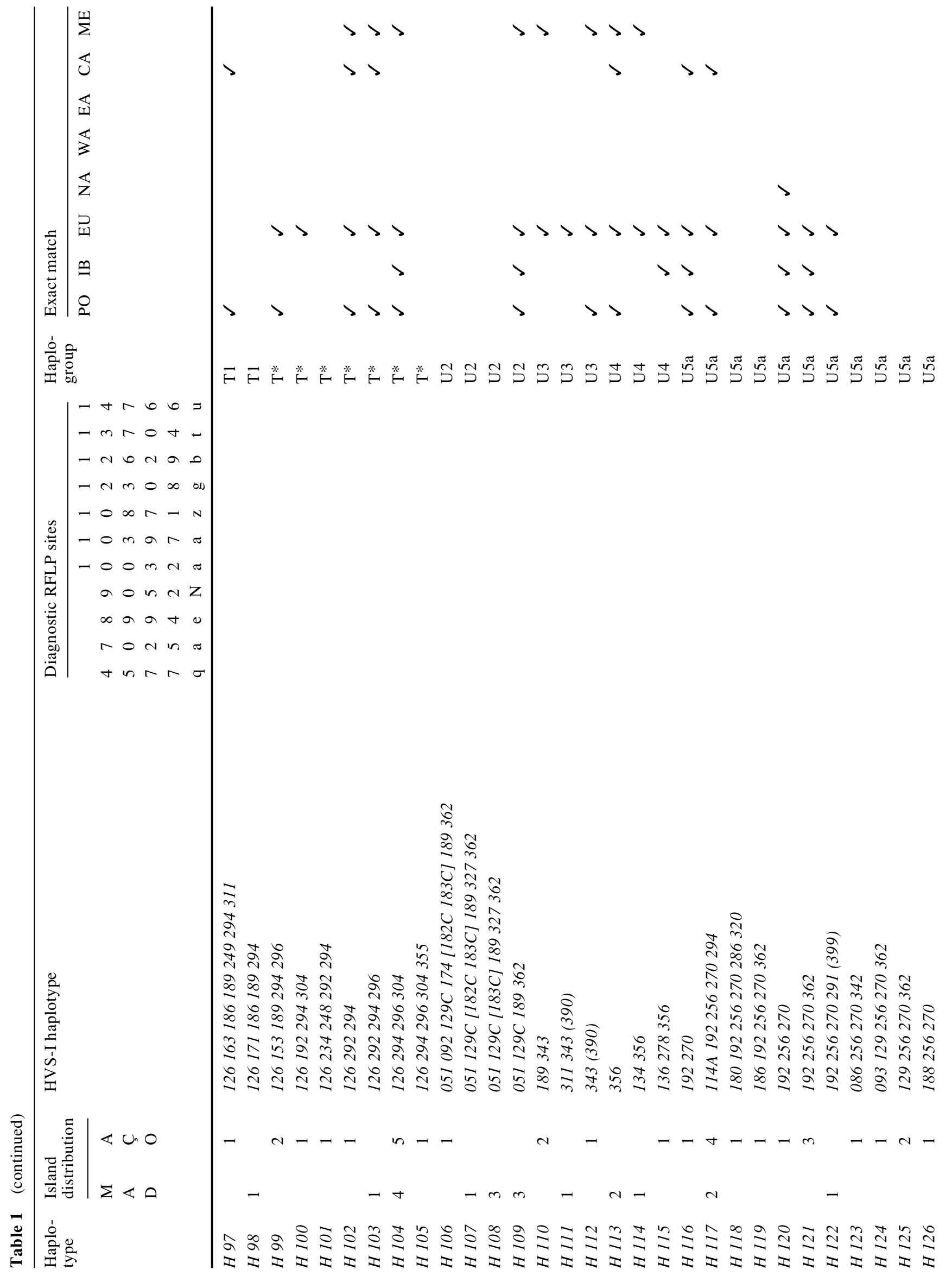




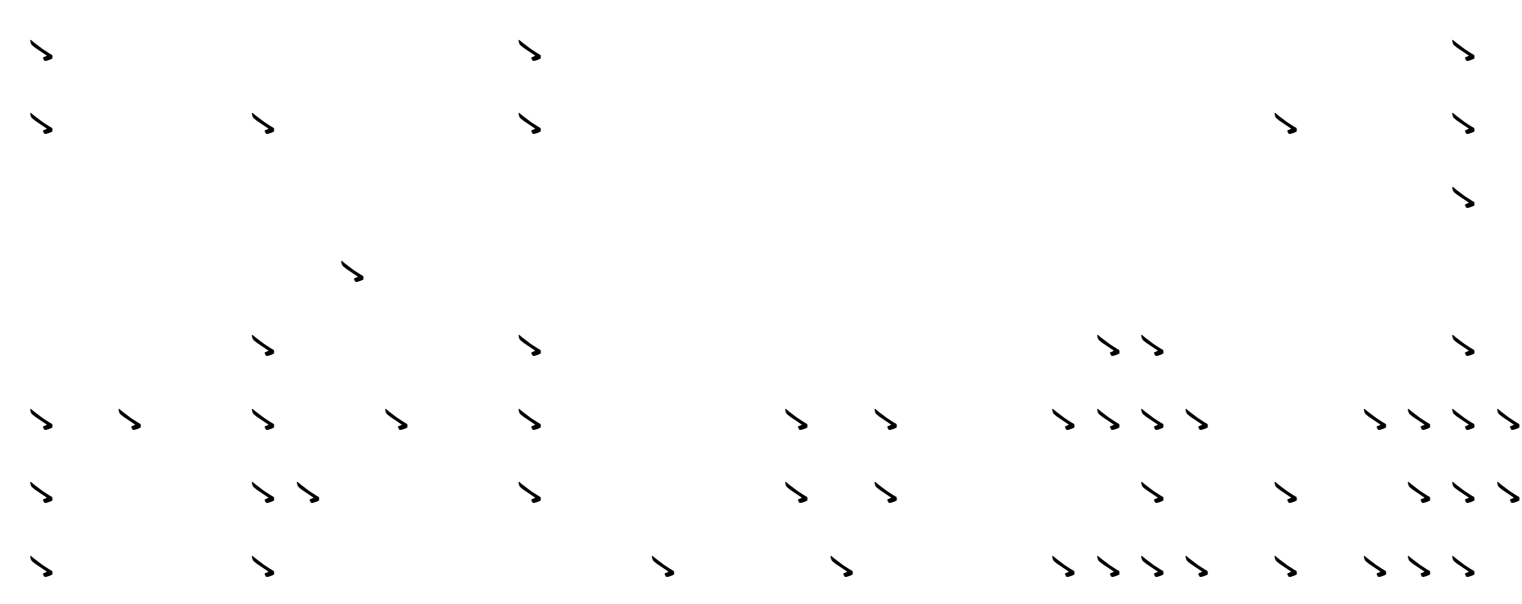

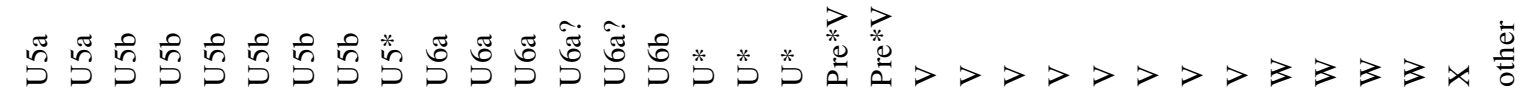
$++++1$
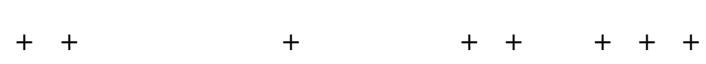

$+$

$++\quad++$

๗ֶ๊

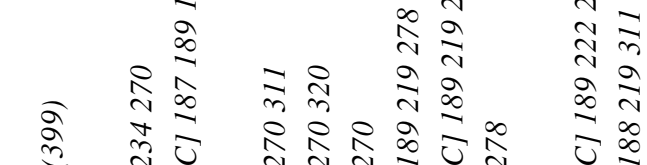

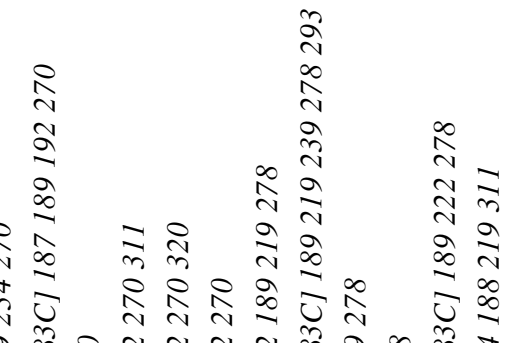

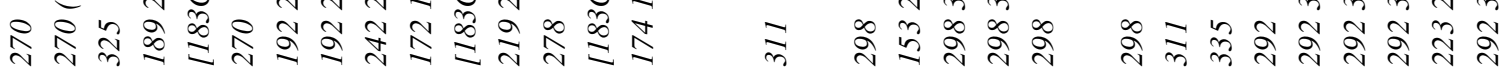
ปे

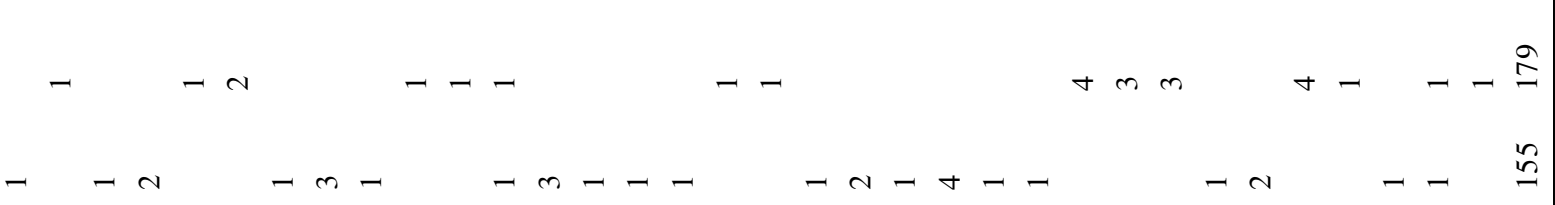

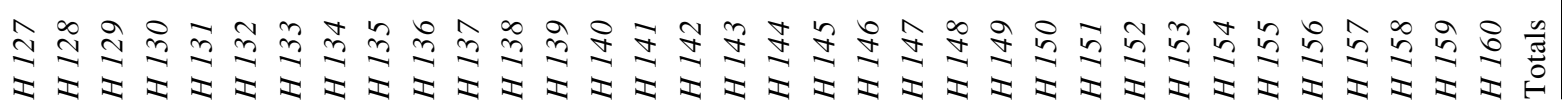


Table 2 Frequencies of the main haplogroups found in Madeira and Açores archipelagos, as well as in Portugal, Canary Islands, Cabo Verde and North Africa ( $n$ is the sample number; MA Madeira,
$A C ̧$ Açores, $P N$ Portugal North, $P C$ Portugal Central, $P S$ Portugal South, $N A$ North Africa, $C V$ Cabo Verde, $C A$ Canary Islands, $M E$ Middle East)

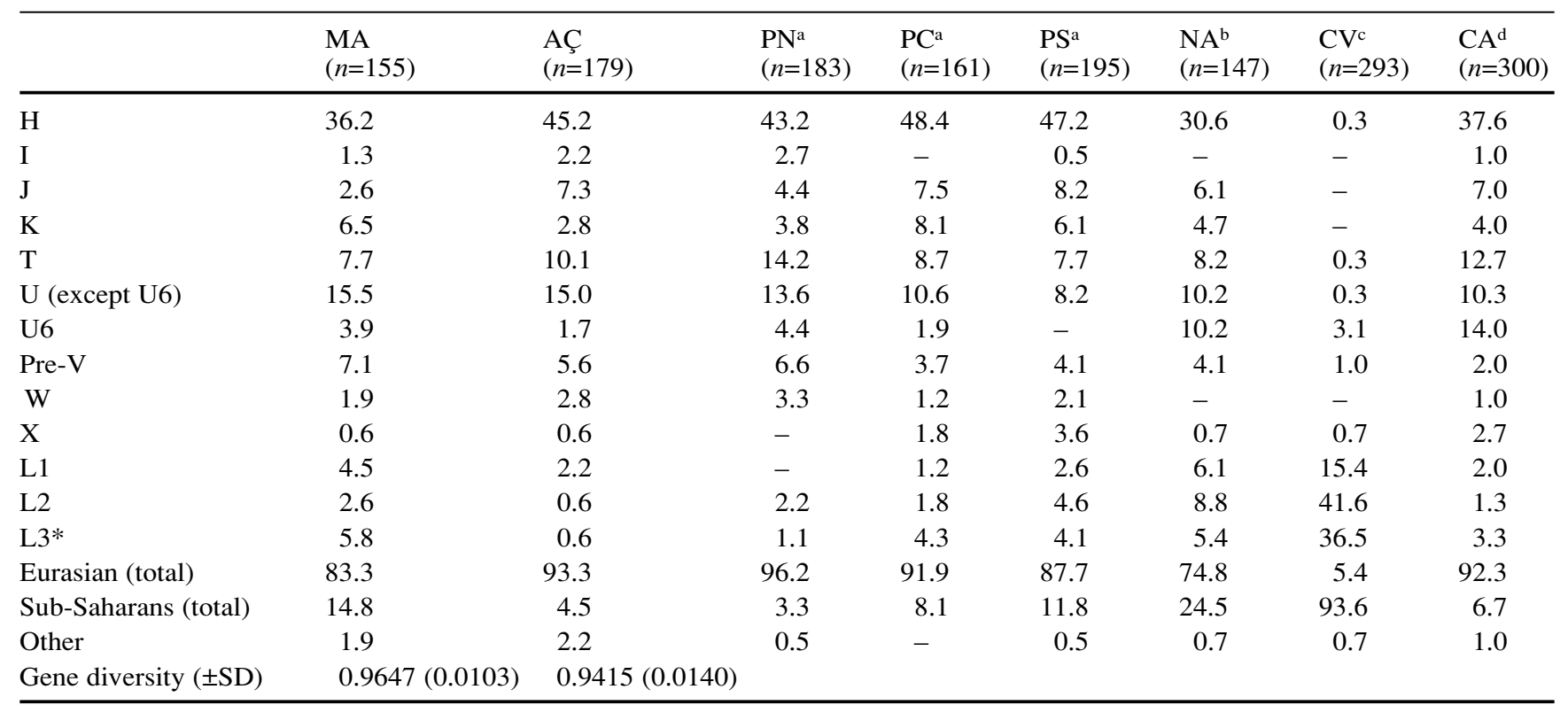

aPooled data from González et al. (2003) and Pereira et al. (2000)

bData from Rando et al. (1998)

'Data from Brehm et al. (2002)

dData from Rando et al. (1999)

Fig. 1 Principal component analysis of mtDNA frequencies. Population codes are as follows: $M A$ Madeira, $A C$ Açores, $P N$ Portugal North, $P C$ Portugal Centre, PS Portugal South, NA North Africa, $C A$ Canary Islands. Axis 1 and 2 extracted $61.59 \%$ and $22.71 \%$ of the information, respectively

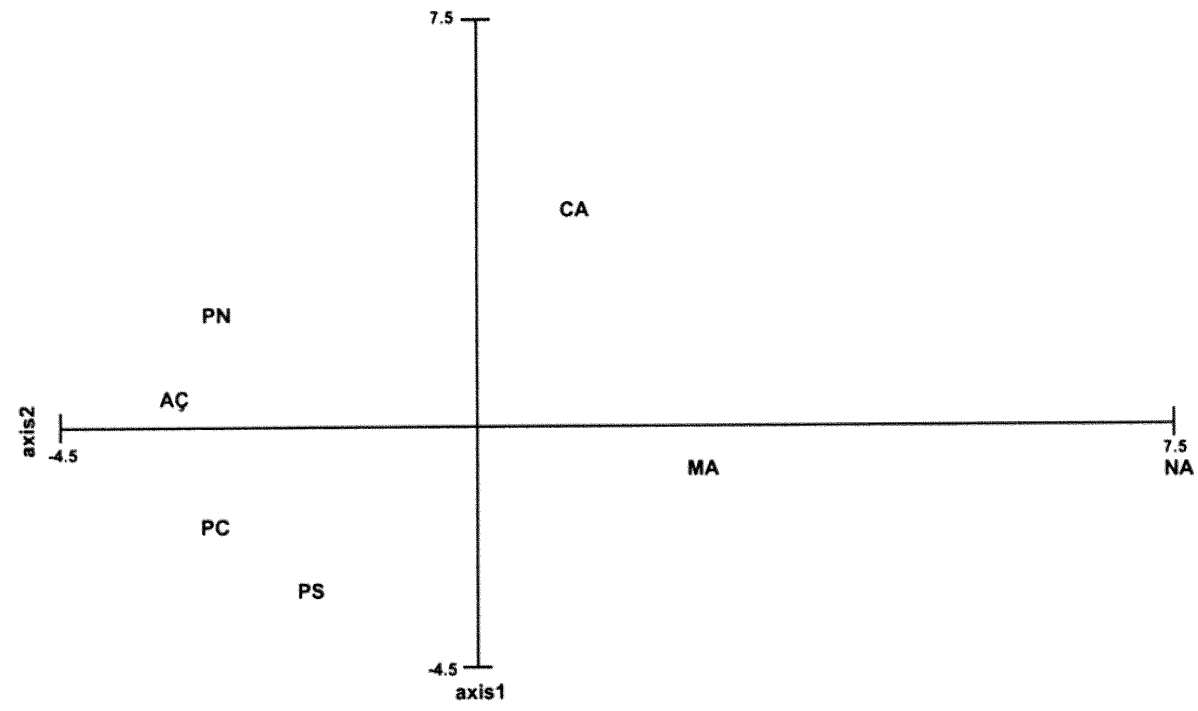

Relatively high frequency of sub-Saharan L and M1 haplogroups (14\%; Table 2) in Madeira is consistent with the historical records on slave's introduction both in the south of Portugal and in Madeira (Godinho 1965). Also, the African input in Madeira is significantly higher than in the Açores $(Z=3.26, P<0.0001)$ and still higher than in the Canary Islands $(P<0.05)$, which nevertheless also had a strong introduction of sub-Saharan slave labour. Haplogroup M1 is absent or rare in West African and North African populations (Salas et al. 2002), rendering it possible that its presence in Madeira is due to an introduction via mainland Portugal, where related M1 sequences have been sampled (González et al. 2003; Pereira et al. 2000). Haplogroup U5 is spread across Europe, but particular U5b haplotypes have also been found in some sub-Saharan populations among Wolof and Serer (Rando et al. 1998) and Guineans (our data, unpublished).

Both Madeira and Açores were uninhabited before their discovery contrary to the Canaries, which were populated by North African Guanches. These autochthonous people are supposed to date to pre-Neolithic times and show the presence of a particular U6b1 haplotype characterized by 
a transition at np 16163 (Rando et al. 1999). Although the presence of Guanches in Madeira is well documented, we could not find the particular "Canary" haplotype in our Madeiran sample. Notably, all haplotypes with an exact match between Madeira and the Canaries also appear in mainland individuals, thus rendering it difficult to estimate the gene flow among these islands that had tight historical contacts. The frequency of the typical North-African haplogroup U6 is significantly $(P<0.0001)$ higher in Canaries (14\%) than in Madeira (3.9\%). From the U6 haplotypes found in Madeira and Açores, only one (H141) shows an exact match in Iberia, not surprisingly in the north of Portugal the region concentrating almost all U6s in Portugal (González et al. 2003; Pereira et al. 2000). U6 is well represented in the Canary Islands, but no exact matches with Madeira and Açores were found, suggesting a parallel gene flow from North Africa rather than an introduction via the Canary Islands. The relatively high proportion of matches between Madeira and the Açores can be explained as a parallel process of settlement or by direct gene flow between islands. Settlers from Madeira and Açores were mainly from the Portuguese mainland, but there was also a remarkable inflow of north-European people, especially to Açores (Frutuoso 1977; Mendonça 1996). It is also well documented that many settlers to the Açores were from Madeira (Mendonça 1996). Concerning Madeira, there is an on-going debate over the geographic origin of the Portuguese settlers. From the total haplotype sharing between Madeira and mainland Portugal, 32\% correspond to matches located exclusively in the north of the country. Although both archipelagos have similar diversity values (Açores= $0.941 \pm 0.14$, Madeira $=0.9647 \pm 0.010$ ) it is the proportion of African haplotypes that makes the difference. In fact, sub-Saharan haplotypes found in Madeira could have been present in the migrant Iberian population or introduced with the slave trade directly from Cabo Verde. It is thus necessary to find out if the introduced African haplotypes are part of the original Iberian mtDNA gene pool or not. The Arab and Berber presence in Portugal lasting almost 700 years could have introduced the sub-Saharan haplotypes into Iberian Peninsula, but should this be the case it is less perceivable why these should be concentrated in the south of the country (González et al. 2003; Pereira et al. 2000) and why most haplotypes found in Madeira do not have exact matches in Portugal. The sub-Saharan component in Madeira is not likely to have its origin in North Africa, considering the comparatively low proportion of common matches between the two regions. Our data suggest that the African input, at least in Madeira, is due to a direct import of slaves from West Africa (whose haplotypes are not captured in the databases surveyed) and not an indirect input via Portugal or North Africa.

Principal component analysis (PCA) distinguishes the populations of North African, Madeira, and Canary Islands from mainland Portugal and the Açores (Fig. 1). The highest weight in the plot is due to the sub-Saharan L lineages and haplogroup U6. The relatively high proportion of African lineage clusters L1-L3, U6, and M1 in Madeira $(18.7 \%)$ and only $5.1 \%$ in the Açores agrees well with pre- vious estimates of African admixture based on HLA and STR markers (Spínola et al. 2002; Fernandes et al. 2003).

Acknowledgements The authors are grateful for the precious help of the Portuguese Army Chief of Staff. Dr José Jesus provided analytical help. L.P. was supported by a grant from Fundação para a Ciência e a Tecnologia (SFRH/BDP/7121/2001). Programa Operacional Ciência, Tecnologia e Inovação (POCTI), Quadro Comunitário de Apoio III, supports IPATIMUP.

\section{References}

Anderson S, Bankier AT, Barrel BG, De Bruijn MHL, Coulson AR, Drouin J, Eperon IC, Nierlich DP, Roe BA, Sanger F, Schreier PH, Smith AJH, Staden R, Young G (1981) Sequence and organization of the human mitochondrial genome. Nature 290:457-465

Bendall KE, Sykes BC (1995) Length heteroplasmy in the first hypervariable segment of the human mtDNA control region. Am J Hum Genet 57:248-256

Brehm A, Pereira L, Bandelt H-J, Prata MJ, Amorim A (2002) Mitochondrial portrait of the Cabo Verde archipelago: the Senegambian outpost of Atlantic slave trade. Ann Hum Genet 66:49-60

Carreira A (1983) Migrações nas ilhas de Cabo Verde, 2nd edn. Instituto Caboverdeano do Livro, Lisboa.

Côrte-Real HBSM, Macaulay VA, Richards MB, Hariti G, Isaad MS, Cambon-Thomsen A, Papiha S, Bertranpetit J, Sykes BC (1996) Genetic diversity in the Iberian Peninsula determined from mitochondrial sequences analysis. Ann Hum Genet 60: 331-350

Fernandes A, Velosa R, Jesus J, Carracedo A, Brehm A (2003) Genetic differentiation of the Cabo Verde Archipelago population analysed by STR polymorphisms. Ann Hum Genet 67:340-347

Finnilä S, Hassinen I, Ala-Kokko A, Majamaa K (2000) Phylogenetic network of the mtDNA Haplogroup U in northern Finland based on sequence analysis of the complete coding region by conformation-sensitive gel electrophoresis. Am J Hum Genet 66:1017-1026

Frutuoso G (1977) Saudades da Terra, (written in 1580-1591) Livro IV, vol I. Instituto Cultural de Ponta Delgada, Ponta Delgada

Godinho VM (1965) Os Descobrimentos e a Economia Mundial, vol 1, 2. Arcádia, Lisboa

González AM, Brehm A, Pérez J, Maca-Meyer N, Flores C, Cabrera V (2003) Mitochondrial DNA affinities at the Atlantic fringe of Europe. Am J Phys Anthropol 120:391-404

Long JC (1991) The genetic structure of admixed populations. Genetics $142: 417-428$

Mendonça L (1996) História dos Açores. Visão Geral (séc. XV-XIX). Centro de Apoio Tecnológico à Educação, Ponta Delgada

Pereira ECN (1989) Ilhas de Zarco, 4th edn, vol II. Câmara Municipal Funchal, Funchal

Pereira L, Prata MJ, Amorim A (2000) Diversity of mtDNA lineages in Portugal: not a genetic edge of European variation. Ann Hum Genet 64:491-506

Rando JC, Pinto F, González AM, Hernández M, Larruga JM, Cabrera VM, Bandelt H-J (1998) Mitochondrial DNA analysis of Northwest African populations reveals genetic exchanges with European, Near-Eastern, and sub-Saharan populations. Ann Hum Genet 62:531-550

Rando JC, Cabrera VM, Larruga JM, Hernández M, González AM, Pinto F, Bandelt H-J (1999) Phylogeographic patterns of mtDNA reflecting the colonization of the Canary Islands. Ann Hum Genet 63:413-428 
Richards M, Macaulay V, Hickey E, Vega E, Sykes B, Guida V, Rengo C, Sellitto D, Cruciani F, Kivisild T, Villems R, Thomas M, Rychkov S, Rychkov O, Rychkov Y, Gölge M, Dimitrov D, Hill E, Bradley D, Romano V, Calì F, Vona G, Demaine A, Papiha S, Triantaphyllidis C, Stefanescu G, Hatina J, Belledi M, Di Rienzo A, Novelletto A, Oppenheim A, Nørby S, Al-Zaheri N, Santachiara-Benerecetti S, Torroni A, Bandelt H-J (2000) Tracing European founder lineages in the Near Eastern mtDNA pool. Am J Hum Genet 67:1251-1276

Russell-Wood AJ (1998) The Portuguese empire, 1415-1808. A world on the move. Johns Hopkins University Press, Baltimore

Salas A, Comas D, Lareu MV, Bertranpetit J, Carracedo A (1998) mtDNA analysis of the Galician population: a genetic edge of European variation. Eur J Hum Genet 6:365-375

Salas A, Richards M, De la Fé T, Lareu M-V, Sobrino B, SánchezDiz P, Macaulay V, Carracedo A (2002) The making of the African mtDNA landscape. Am J Hum Genet 71:1082-1111

Spínola H, Brehm A, Williams F, Jesus J, Middleton D (2002) Distribution of HLA alleles in Portugal and Cabo Verde. Relationships with the slave trade route. Ann Hum Genet 66:285296
Torroni A, Huoponen K, Francalacci P, Petrozzi M, Morelli L, Scozzari R, Obinu D, Savontaus ML, Wallace DC (1996) Classification of European mtDNAs from an analysis of three European populations. Genetics 144:1835-1850

Torroni A, Bandelt HJ, Macaulay V, Richards M, Cruciani F, Rengo C, Martinez-Cabrera V, Villems R, Kivisild T, Metspalu E, Parik J, Tolk HV, Tambets K, Forster P, Karger B, Francalacci P, Rudan P, Janicijevic B, Rickards O, Savontaus ML, Huoponen K, Laitinen V, Koivumaki S, Sykes B, Hickey E, Novelletto A, Moral P, Sellitto D, Coppa A, Al-Zaheri N, Santachiara-Benerecetti AS, Semino O, Scozzari R (2001) A signal, from human mtDNA, of postglacial recolonization in Europe. Am J Hum Genet 69:844-852

Vigilant L, Pennington R, Harpending H, Kocher TD, Wilson AC (1989) Mitochondrial DNA sequences in single hairs from a southern African population. Proc Natl Acad Sci USA 86: 9350-9354 